\title{
Organic and Mineral Fertilizer on the Initial Development and Nutrition of Jatropha
}

\author{
Aline Cristina de Souza Reis ${ }^{1}$, Tiago Roque Benetoli da Silva ${ }^{1}$, Affonso Celso Gonçalves-Júnior ${ }^{2}$, Deonir Secco ${ }^{2}$, \\ Charline Zaratim Alves $^{3} \&$ Reginaldo Ferreira Santos $^{2}$ \\ ${ }^{1}$ Universidade Estadual de Maringá, Maringá, PR, Brazil \\ ${ }^{2}$ Universidade do Oeste do Paraná, Campus de Marechal Cândido Rondon e Cascavel, PR, Brazil \\ ${ }^{3}$ Universidade Federal do Mato Grosso do Sul, Chapadão do Sul, MS, Brazil \\ Correspondence: Tiago Roque Benetoli da Silva, Departamento de Ciências Agronômicas, Universidade \\ Estadual de Maringá, Avenida Colombo n. 5790, CEP: 87020-900, Maringá, PR, Brazil. E-mail: \\ trbsilva@uem.br
}

Received: February 7, 2018

doi:10.5539/jas.v10n10p274

\author{
Accepted: April 7, $2018 \quad$ Online Published: September 15, 2018 \\ URL: https://doi.org/10.5539/jas.v10n10p274
}

\begin{abstract}
Jatropha (Jatropha curcas L.) is an herbaceous plant, perennial, belonging to the family of Euphorbiaceaes. Jatropha's extract is used for the harvest of fruits, high amount of nutrients and, if not properly fertilized, can lead to the impoverishment of the soil over the years of cultivation. Thus, in this present work, we have a concern with the importance of fertilization. The experiment was conducted under field conditions in the 2014/2015 agricultural year, in São Jorge do Patrocínio, State of Parana, Brazil. The experiment was conducted in a randomized block design with five replications and five treatments, totaling 25 installments. The treatments were as follows: organic fertilization (total rate: $2,800 \mathrm{~g} \mathrm{plant}^{-1}$ ), mineral fertilizers with nitrogen, phosphorus and potassium (total rate: $174.4 \mathrm{~g} \mathrm{plant}^{-1}$, and $13.2 \mathrm{~g}$ plant $^{-1}$ of urea, $141.2 \mathrm{~g} \mathrm{plant}^{-1}$ of superphosphate and $20 \mathrm{~g}$ plant $^{-1}$ of potassium chloride), $75 \%$ organic fertilizer $+25 \%$ mineral, $50 \%$ organic fertilizer $+50 \%$ mineral, $25 \%$ organic $+75 \%$ mineral, applied at planting. Poultry litter was used as the organic fertilizer source, the nitrogen source was urea, the phosphorus source was superphosphate and, the potassium source was potassium chloride. Spacing of $2 \times 2 \mathrm{~m}$ between plants and the pits with $30 \times 30 \times 30 \mathrm{~cm}$. The evaluated variables were: plant height, stem diameter, contents macro and micronutrients in leaves. It can be concluded that there was no influence of mineral and organic fertilization on the initial growth of jatropha. As for the macronutrient levels, there were no significant differences for $\mathrm{P}$ and $\mathrm{K}$. However, regarding the mineral fertilizer and the micronutrient content, there was a significant difference in $\mathrm{Mn}$, in the treatment with total rate of mineral fertilizer and in the treatment with $25 \%$ organic fertilizer and $75 \%$ mineral fertilizer.
\end{abstract}

Keywords: Jathopha curcas L., family farms, biodiesel, sustainability, biofuel

\section{Introduction}

The Euphorbiaceae family comprises approximately 8000 species, with about 320 genera. The Jatropha genus contains approximately 160 species of herbaceous and shrub plants, of which medicinal, ornamental value and others produce oil, as is the case of Jatropha curcas L. (Nunes \& Paqual 2007).

The jatropha plant may have various uses, such as: medicinal, ornamental, hedge and oil production. The pie remaining from seed pressing is a fertilizer rich in nitrogen, potassium, phosphorus and organic matter, but it is not recommended for use in animal feed without adequate treatment. Another use of jatropha solid wastes can be, as observed in other organic wastes, such as pine bark, its use as charcoal and raw material in papermaking and boiler feed for steam production and bioelectricity (Gusmão, 2010).

Biodiesel is a fuel produced from vegetable oils, animal fats and algae. There are dozens of plant species present in Brazil that can be used in the production of biodiesel, among them: soybean, palm, sunflower, babassu, peanut, castor bean and Jatropha (Heller, 1996, Ceará Biodiesel, 2007).

Jatropha oil is composed mainly of oleic (41\%) and linoleic acids (37\%), followed by palmitic (13.3\%) and stearic acids (6.4\%) (Bicudo et al., 2007). Biodiesel was used as a raw material for both the methyl and ethyl 
routes, presenting physico-chemical characteristics compatible with Resolution 42 of the National Petroleum Agency (ANP) (Araújo et al., 2007).

The seeds are the oil source in the jatropha plant. Dantas et al. (2009), and Morais et al. (2007), state that the production and commercialization of high quality physiological jatropha seeds, one should harvest the yellowish fruits with brown parts.

According to Laviola and Dias (2008), jatropha extracts a high amount of nutrients from fruit harvesting and, if not properly fertilized, it can lead to soil impoverishment over the growing years.

Additionally, the response of the Jatropha culture to a monoculture system shows that it is a plant susceptible to pests, diseases, water deficit and soils with low fertility. The occurrence of diseases and pest attacks has been widely reported in experimental and commercial plantations in Brazil and in the world (Heller, 1996; Saturnino et al., 2005; Jongschaap et al., 2007; Gonçalves et al., 2009).

Studies on jatropha are mostly restricted to the young plant, with one or two years of cultivation. Since it is a perennial crop and reaches its peak of production around the 5th year of cultivation, there is a greater need for studies on year-to-year fertilization.

The aim of the present study was to evaluate the effect of organic and mineral fertilization on initial growth of jatropha, as well as its nutrition.

\section{Method}

The experiment was conducted under field conditions in the 2014/2015 agricultural year of, located in the city of São Jorge do Patrocínio, whose latitude and longitude are $23^{\circ} 45^{\prime} 45^{\prime \prime} \mathrm{S}, 53^{\circ} 52^{\prime} 39^{\prime \prime} \mathrm{W}$, respectively. According to the climate classification of Köppen-Geiger, the climate is humid subtropical.

The soil of the site is classified as typical Distrophic Red Argisol (Embrapa, 2013), and the soil samples collected before the experiment were in the $0-20 \mathrm{~cm}$ depth layer: $8.9 \mathrm{mg} \mathrm{dm}^{-3}$ phosphorus (Mehlich 1), $5.98 \mathrm{pH}$ in $\mathrm{CaCl}_{2}, 0.41,2.63,0.75$ and $5.67 \mathrm{cmolc} \mathrm{dm}^{-3}$ of $\mathrm{K}, \mathrm{Ca}, \mathrm{Mg}$ and CTC, respectively, $7.8 \mathrm{~g} \mathrm{~kg}^{-1}$ of organic matter, base saturation of $61.36 \%, 80.5,20$ and $899.5 \mathrm{~g} \mathrm{~kg}^{-1}$ of clay, silt and sand, respectively.

The experiment was carried out in a randomized complete block design, with five treatments and five replications, totaling 25 plots. The studies involving chemical and organic fertilization for the jatropha culture are still incipient, and sometimes provide divergent technical information, Although there are different studies, in which there is a lack of information on crop conditions (soil, climate and management), we used the recommended fertilization for castor bean in this experiment, according to Savi Filho (1998), which consists of mineral fertilization with $15 \mathrm{~kg} \mathrm{ha}^{-1}$ of N, $60 \mathrm{~kg} \mathrm{ha}^{-1}$ of $\mathrm{P}_{2} \mathrm{O}_{5}$ and $30 \mathrm{~kg} \mathrm{ha}^{-1}$ of $\mathrm{K}_{2} \mathrm{O}$.

Regarding, as for organic fertilization, the chicken manure (with fattening residues from two lots of chickens with periods of 43 days each), the dose of $7 \mathrm{t} \mathrm{ha}^{-1}$ was used. The treatments were as it follows: organic fertilization (total dose: $2,800 \mathrm{~g} \mathrm{plant}^{-1}$ ), mineral fertilization with nitrogen, phosphorus and potassium (total dose: $174.4 \mathrm{~g} \mathrm{plant}^{-1}$, being $13.2 \mathrm{~g}$ plant $^{-1}$ urea, $141.2 \mathrm{~g}$ plant $^{-1}$ simple superphosphate and $20 \mathrm{~g}$ plant $^{-1}$ potassium chloride), $75 \%$ organic fertilization $+25 \%$ mineral, $50 \%$ organic fertilization $+50 \%$ mineral, $25 \%$ organic fertilization $+75 \%$ mineral fertilization, applied at the time of planting. Concerning, as for organic fertilization, we used, chicken manure as biofertilization source. As for mineral fertilization, the source of nitrogen was urea, for phosphorus, simple superphosphate and for potassium, potassium chloride. It was used $2 \times 2 \mathrm{~m}$ of spacing between plants and in the pits $30 \times 30 \times 30 \mathrm{~cm}$ were used.

The planting area was desiccated and the planting was done manually on June 28, 2014, whose seeds for seedling formation were sown in substrate tubes on April 21, 2014. Weeds were eliminated soon after its emergence, and there was no need for control of pests and diseases. Every 30 days, during the 12-month period, the following characteristics were evaluated: plant height and plant stem diameter, with the aid of a measuring tape and a caliper rule, respectively. A leaf diagnosis was made using 10 leaves of each experimental plot, collected after 06 months and at the height of the middle third of the plant, being washed with distilled water and placed in a forced air ventilation oven at $60-70{ }^{\circ} \mathrm{C}$, for 72 hours. Macronutrients $(\mathrm{P}, \mathrm{K}, \mathrm{Ca}$ and $\mathrm{Mg}$ ) and micronutrients (B, Zn, Fe and Mn) were analyzed following the methodology of Malavolta, Vitti, and Oliveira (1997), and all samples were ground in a stainless steel mill, weighed and placed in test tubes, which were placed in digestion blocks, using the digester solution and the perchloric nitric acid together with the samples. After digestion, the samples were submitted to the analyzes already mentioned.

Statistical analysis was performed following the variance analysis model, using the Sisvar program, using the 5\% level of significance. The averages were compared by the Tukey test, with the same level of significance. 


\section{Results}

For plant height, there was no significant difference between treatments (Table 1). Through the soil analysis it is possible to interpret that nutrient $\mathrm{K}$ was at medium level and this may have led to the not significant results of fertilization management, since the soil exhibited chemical characteristics relatively adequate to the plants still in early development, ally to the irregular rainfall, limiting growth characteristics (height and stem diameter).

Table 1. Height of plants of jatropha in function of planting fertilization. São Jorge do Patrocínio, PR, 2014-15

\begin{tabular}{lllllllllll}
\hline \multirow{2}{*}{ Treatments } & \multicolumn{10}{c}{ Height of plants (cm) } \\
\cline { 2 - 11 } & $8 / 14$ & $9 / 14$ & $10 / 14$ & $11 / 14$ & $12 / 14$ & $1 / 15$ & $2 / 15$ & $3 / 15$ & $4 / 15$ & $5 / 15$ \\
\hline Organic (O) & 11.6 & 14.8 & 21.0 & 37.2 & 54.2 & 76.2 & 99.6 & 121.0 & 136.8 & 151.6 \\
Mineral (M) & 13.4 & 16.6 & 21.6 & 31.0 & 58.2 & 65.4 & 97.8 & 126.0 & 145.4 & 162.4 \\
$50 \% \mathrm{O}+50 \% \mathrm{M}$ & 12.0 & 17.7 & 25.0 & 41.0 & 57.3 & 79.0 & 107.5 & 130.8 & 147.7 & 165.0 \\
$25 \% \mathrm{O}+75 \% \mathrm{M}$ & 12.8 & 17.8 & 25.2 & 38.9 & 53.4 & 81.4 & 107.4 & 127.6 & 140.0 & 161.0 \\
$75 \% \mathrm{O}+25 \% \mathrm{M}$ & 12.2 & 16.5 & 22.0 & 40.8 & 58.6 & 80.8 & 109.4 & 132.6 & 149.8 & 162.4 \\
\hline Test F & n.s. & n.s. & n.s. & n.s. & n.s. & n.s. & n.s. & n.s. & n.s. & n.s. \\
\hline C.V. $(\%)$ & 20.5 & 18.3 & 19.3 & 17.8 & 17.7 & 21.4 & 20.1 & 17.7 & 17.6 & 17.4 \\
\hline
\end{tabular}

Note. n.s. $=$ not significant; C.V. $=$ coefficient of variation.

For plant stem diameter, no significant difference was found between fertilization management (Table 2).

Table 2. Stem diameter of jatropha plants in function of planting fertilization. São Jorge do Patrocínio, PR, 2014-15

\begin{tabular}{lllllllllll}
\hline \multirow{2}{*}{ Treatments } & \multicolumn{10}{c}{ Plant diameter (cm) } \\
\cline { 2 - 10 } & $8 / 14$ & $9 / 14$ & $10 / 14$ & $11 / 14$ & $12 / 14$ & $1 / 15$ & $2 / 15$ & $3 / 15$ & $4 / 15$ & $5 / 15$ \\
\hline Organic(O) & 2.9 & 3.3 & 4.0 & 5.9 & 7.7 & 10.2 & 14.0 & 16.7 & 19.0 & 21.0 \\
Mineral (M) & 2.8 & 3.4 & 3.8 & 5.3 & 7.6 & 9.6 & 12.6 & 15.3 & 18.0 & 20.1 \\
$50 \% \mathrm{O}+50 \% \mathrm{M}$ & 2.9 & 3.7 & 4.6 & 6.5 & 8.3 & 11.5 & 15.0 & 17.4 & 18.7 & 20.3 \\
$25 \% \mathrm{O}+75 \% \mathrm{M}$ & 2.9 & 3.6 & 4.7 & 6.2 & 8.6 & 11.2 & 14.0 & 16.5 & 18.5 & 20.7 \\
$75 \% \mathrm{O}+25 \% \mathrm{M}$ & 2.9 & 3.6 & 4.2 & 6.3 & 8.8 & 11.4 & 14.8 & 17.6 & 19.4 & 21.7 \\
\hline Test F & n.s. & n.s. & n.s. & n.s. & n.s. & n.s. & n.s. & n.s. & n.s. & n.s. \\
\hline C.V. $(\%)$ & 9.0 & 9.5 & 13.4 & 14.6 & 15.7 & 18.1 & 18.7 & 18.5 & 18.9 & 15.8 \\
\hline
\end{tabular}

Note. n.s. $=$ not significant; C.V. $=$ coefficient of variation.

A significant difference was observed in the treatment with mineral fertilization in the phosphorus $(\mathrm{P})$ and potassium $(\mathrm{K})$ contents. The analysis of variance indicates that the treatment with mineral fertilization favored the levels of the macronutrients $\mathrm{P}$ and $\mathrm{K}$, compared to the other treatments used.

In Table 4, it is possible to observe the significant difference in the treatment with mineral fertilization (total dose and $25 \% \mathrm{O}+75 \% \mathrm{M}$ ) only in the manganese content.

It can be observed that where there is a significant difference in the Mn content, it occurs in the treatments with the highest amount of mineral fertilization, as the total dose of mineral fertilizer $(100 \%)$ and dose of $25 \%$ organic fertilizer $+75 \%$ mineral fertilizer. The organic fertilizer, when used in high quantities, may have complexed part of the manganese in soil, possibly because $\mathrm{Mn}$ is a heavy metal, which may have an effect on this phenomenon due to the increase of organic matter. According to Olumu et al. (1972), and McBride (1892), Mn forms stable complexes with organic linkers. 
Table 3. Macronutrients content $\left(\mathrm{g} \mathrm{kg}^{-1}\right)$ in leaves of Jatropha in function of planting fertilization. São Jorge do Patrocínio, PR, 2014-15

\begin{tabular}{|c|c|c|c|c|}
\hline Treatments & Phosphorus & Potassium & Calcium & Magnesium \\
\hline & \multicolumn{4}{|c|}{ 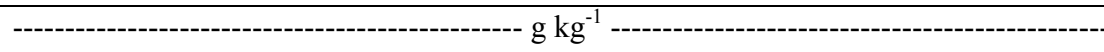 } \\
\hline Organic $(\mathrm{O})$ & $0.95 \mathrm{~b}$ & $23.3 \mathrm{~b}$ & 12.7 & 10.2 \\
\hline Mineral (M) & $1.30 \mathrm{a}$ & $26.5 \mathrm{a}$ & 17.4 & 10.8 \\
\hline $50 \% \mathrm{O}+50 \% \mathrm{M}$ & $0.88 \mathrm{~b}$ & $21.2 \mathrm{~b}$ & 18.7 & 11.2 \\
\hline $25 \% \mathrm{O}+75 \% \mathrm{M}$ & $0.70 \mathrm{~b}$ & $21.3 \mathrm{~b}$ & 16.2 & 10.5 \\
\hline $75 \% \mathrm{O}+25 \% \mathrm{M}$ & $0.83 \mathrm{~b}$ & $22.1 \mathrm{~b}$ & 17.3 & 10.8 \\
\hline Test F & $*$ & $*$ & n.s. & n.s. \\
\hline C.V. $(\%)$ & 15.7 & 17.0 & 25.2 & 11.2 \\
\hline
\end{tabular}

Note. Means followed by the same letter in the column, do not differ by Tukey test at $5 \%$ of error probability. * and n.s.: Significant and not significant at 5\% probability of error, respectively. C.V. = coefficient of variation.

Table 4. Micronutrient content $\left(\mathrm{mg} \mathrm{kg}^{-1}\right)$ in leaves of jatropha in function of planting fertilization. São Jorge do Patrocínio, PR, 2014-15

\begin{tabular}{|c|c|c|c|c|}
\hline Treatments & Copper & Zinc & Iron & Manganese \\
\hline & \multicolumn{4}{|c|}{ 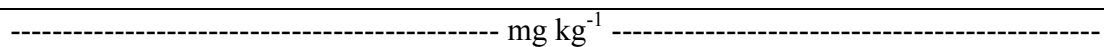 } \\
\hline Organic $(\mathrm{O})$ & 10.6 & 31.0 & 328 & $634 \mathrm{~b}$ \\
\hline Mineral (M) & 9.4 & 30.0 & 419 & $921 \mathrm{a}$ \\
\hline $50 \% \mathrm{O}+50 \% \mathrm{M}$ & 9.8 & 29.3 & 389 & $711 \mathrm{~b}$ \\
\hline $25 \% \mathrm{O}+75 \% \mathrm{M}$ & 8.2 & 26.6 & 453 & $918 \mathrm{a}$ \\
\hline $75 \% \mathrm{O}+25 \% \mathrm{M}$ & 10.4 & 29.2 & 507 & $750 \mathrm{~b}$ \\
\hline Teste F & n.s. & n.s. & n.s. & $*$ \\
\hline C.V. $(\%)$ & 13.9 & 12.7 & 25.0 & 16.8 \\
\hline
\end{tabular}

Note. Means followed by the same letter in the column, do not differ by Tukey test at $5 \%$ of error probability. $*$ and n.s.: Significant and not significant at $5 \%$ probability of error, respectively. C.V. $=$ coefficient of variation.

\section{Discussion}

In other studies, contrasting results about of Jatropha and other plant species were observed in treatments with fertilization. In the experiment on nutrient omission in jatropha plants grown in nutrient solution, Maia et al. (2014), observed that the absence of $\mathrm{N}$ and $\mathrm{P}$ were the ones that affected the macronutrient contents in the aerial part of the jatropha plants, promoting uniform chlorosis of the leaf blades. In the study on Jatropha response to the application of irrigation levels and doses of potassium fertilization, Oliveira et al. (2012), observed that only potassium fertilization, did not affect the growth of irrigated jatropha in the southern region of Minas Gerais.

In the castor bean crop, Severino et al. (2011), found a significant increase in productivity and growth characteristics of the castor bean with the supply of chemical or organic fertilization (average of all treatments that received any fertilization). In addition, the supply of micronutrients associated with adequate doses of organic and mineral fertilizer significantly increased the diameter of the stem.

When comparing organic and mineral fertilization, Carvalho et al. (2011) studied the use of mineral fertilizer and aviary bed, which were applied at the time of sowing, and observed that the height of the soybean plant responded significantly for both treatments. The authors state that this occurred because the experiment was conducted in soil with low fertility and no acidity correction, conditions contrary to those of the present study in which the soil, although sandy, exhibited close to $60 \%$ saturation.

Mineral fertilizers are inorganic salts of different solubilities. The agronomic efficiency depends on its solubility and the chemical reactions with the soil. Nitrogen fertilizers are completely soluble in the soil and can be partially leached. Potassium fertilizers are also soluble, but they present lower losses due to leaching, since the $\mathrm{K}+$ ion is retained at the soil exchange sites, and only the portion at soil solution is removed by water. Phosphate fertilizers have a very variable solubility, depending on the type of phosphate, the thermal or chemical treatment given to the phosphate rock and the predominant soil type (sand, silt or clay) (Giracca \& Nunes, 2012). 
In order that the organic material added to the soil can supply nutrients to the plants, it must be decomposed by the soil microorganisms, and the nutrients retained in its organic structures be released (mineralized). This process of mineralization is influenced by characteristics of the organic material and the environmental conditions of temperature, humidity, aeration and acidity (Correia \& Andrade, 1999).

Figueroa et al. (2012) found that the use of chicken manure doses did not increase the levels of phosphorus, potassium, calcium, magnesium and micronutrients in wheat grains. Carvalho et al. (2011) compared the conventional mineral fertilization and the use of chicken litter in soybean, and verified that soybean yield with chicken manure application was similar to that obtained by the use of mineral fertilizer, only at very high doses of organic fertilizer.

For Kumar and Pandey (1979), elements with high mobility in the phloem, such as N, P and K, are found in greater quantities in the younger leaves. However, nutrients such as calcium $(\mathrm{Ca})$ and magnesium $(\mathrm{Mg})$ tend to concentrate in older tissues in function of the low redistribution capacity (Pathar \& Pandey, 1976, Caldeira et al., 2002). Phosphorus has great mobility in the phloem and is a nutrient closely linked to the physiological processes of energy flow (Marschner, 2002).

The Mn is considered an element of low mobility in the phloem (Marschner, 2002). In older leaves Mn tends to accumulate and is not influenced by the presence of flowers on the branch (Pathar \& Pandey, 1976).

Among other factors, variations in leaf nutrient accumulation may be related to the stage of development of the plant and leaves, the position of the leaf in the branch, the type of branch and the period of sampling (Freiberger, 2012). Lima et al. (2011a) concluded that the $2 \mathrm{nd}$ and the 3rd jatropha leaves nodes, from the apex direction to the based of the secondary branches, are the most suitable for leaf analysis of $\mathrm{N}, \mathrm{P}, \mathrm{K}, \mathrm{S}, \mathrm{Cu}, \mathrm{Fe}, \mathrm{Mn}$ and $\mathrm{Zn}$, which present more stable average values when compared to other studied positions. These authors also determined that the 5th and the 10th leaves nodes are more appropriate for evaluation of $\mathrm{Ca}$ and $\mathrm{Mg}$ and that the phenological stage of the branch does not influence the contents of nutrients, except from $\mathrm{Cu}$ and $\mathrm{Fe}$. The leaves collected for analysis belonged to the middle third of the plant.

The critical level of a given nutrient may be physiological or physio-economic. The first describes the relationship between the level of an element in the leaf and growth or production of the plant. The second is defined as the "level" of an element on the leaf below whose production is limited and above which fertilization is not economical (Malavolta, 2006). In addition, the leaf content is influenced by several factors that act and sometimes interact before and after the collection of leaves, such as soil, fertilization, acidity correction, family, species and variety of plant, leaf and part of leaf, as well as climate factors, cultural practices and pests and diseases. Thus, through trial and error experiments, one can establish leaf type, collection season and number of plants sampled (Malavolta, 2006).

Lima et al. (2011a, 2011b) were the pioneers to correlate nutrient leaf content with leaf position in the secondary branch (comparing also the type of branch, vegetative or floriferous), as well as variation of nutrient contents as a function of the phenological stage of the Jatropha leaf.

According to the aforementioned, as well as the lack of information about Jatropha, it is not possible to predict if a given content is adequate.

In order to obtain precise results, the studies conducted with the jatropha culture must be carried out with different parameters and stages of development, as well as in different soil conditions and management.

It can be concluded that there was no difference between mineral and organic fertilization on the initial growth of jatropha. For macronutrient contents, there was a significant difference for the $\mathrm{P}$ and $\mathrm{K}$, only in the mineral fertilization. As for the micronutrient contents, there was a significant difference in the $\mathrm{Mn}$, in the treatment with total dose of mineral fertilizer and in the treatment with $25 \%$ organic fertilizer and $75 \%$ mineral fertilizer.

\section{References}

Araújo, F. D. S., Moura, C. V. R., \& Chaves, M. H. (2007). Caracterização do óleo e biodiesel de pinhão-manso (Jathopha curcas L.). II Congresso da Rede Brasileira de Tecnologia de Biodiesel, Brasília, DF. Anais: MCT/ABIPIT.

Bernardi, A. C. C., Machado, P. L. O. A., Madari, B. E., \& Lucena, R. L. (2007). Carbon and nitrogen estocks of an arenosol under irrigated fruit orchards in semiarid Brazil. Scientia Agricola, 64, 169-175. https://doi.org/ $10.1590 / \mathrm{S} 0103-90162007000200010$ 
Bicudo, T. C., Freire, L. M. S., Albuquerque, A. R., Dantas, M. B., Vasconcelos, A. F. F., Rosenhaim, R., ... Souza, A. G. (2007). Estabilidade e tempo de indução oxidativa do óleo de pinhão-manso para produção de biodiesel. II Congresso da Rede Brasileira de Tecnologia de Biodiesel, Brasília, DF. Anais: CRBTB.

Brito, S. S., \& Santos, A. C. (2010). Decomposição e mineralização de nutrientes em função da aplicação de diferentes fontes de matéria orgânica. Enciclopédia Biosfera, 6, 1-8. Retrieved from http://www.conhecer. org.br/enciclop/2010b/decomposicao.pdf

Caldeira, M. V. W., Rondon Neto, R. M., \& Schumacher, M. V. (2002). Avaliação da eficiência nutricional de três procedências australianas de acácia-negra (Acacia mearnsii de Wild.). Revista Árvore, 26, 615-620. https://doi.org/10.1590/S0100-67622002000500012

Campiolo, F. A., \& Silva, F. F. (2006). Orgânicos: Garantia de saúde e possibilidade de sucesso econômico para o Brasil. Revista Cesumar-Ciências Humanas e Sociais Aplicadas, 11, 145-165.

Carvalho, E. R., Rezende, P. M., Andrade, M. J. B., Passos, A. M. A., \& Oliveira, J. A. (2011). Fertilizante mineral e resíduo orgânico sobre características agronômicas da soja e nutrientes no solo. Revista Ciência Agronômica, 42, 930-939. https://doi.org/10.1590/S1806-66902011000400015

Ceará Biodiesel. (2007). Origem, utilização e distribuição do pinhão-manso. Retrieved from http://cearabiodies el.blogspot.com.br/2007/11/origem-utilizao-e-distribuio-do-pinho.html

Correia, M. E. F., \& Andrade, A. G. (1999). Formação de serapilheira e ciclagem de nutrientes. In G. A. Santos, \& F. A. O. Camargo (Eds.), Fundamentos da matéria orgânica do solo: Ecossistemas tropicais. Porto Alegre: Gênesis. Retrieved from https://ainfo.cnptia.embrapa.br/digital/bitstream/item/137613/1/Tony2015.pdf

Dantas, B. F., Silva, F. F. S., Oliveira, D. A. B., Araújo, M. N., Lira, M. A. P., Silva, P. P., ... Andreo-Souza, Y. (2009). Correlação entre testes de vigor em sementes de pinhão-manso. Informativo Abrates, 19, 451. Retrieved from http://ainfo.cnptia.embrapa.br/digital/bitstream/item/132226/1/42720.pdf

Dias, L. A. S., Leme, L. P., Laviola, B. G., Pallini Filho, A., Pereira, O. L., Carvalho, M., ... Dias, D. C. F. S. (2007). Cultivo de pinhão-manso (Jatropha curcas L.) para produção de óleo combustível (Vol. 1, p. 40). Viçosa, MG.

Embrapa (Empresa Brasileira de Pesquisa Agropecuária). (2013). Sistema Brasileiro de Classificação dos Solos (p. 353). Rio de Janeiro: EMBRAPA/CNPSO. Retrieved from http://www.agrolink.com.br/downloads/ sistema-brasileiro-de-classificacao-dos-solos2006.pdf

Evans, H. J., \& Sorger, G. J. (1966). Role of mineral elements with emphasis on the univalent cations. Annual Review Plant Physiology, 17, 47-76. https://doi.org/10.1146/annurev.pp.17.060166.000403

Figueroa, E. A., Escosteguy, P. A. V., \& WiethöLter, S. (2012). Dose de esterco de ave poedeira e suprimento de nitrogênio à cultura do trigo. Revista Brasileira de Engenharia Agrícola e Ambiental, 16, 714-720. https://doi.org/10.1590/S1415-43662012000700003

Freiberger, M. B. (2012). Crescimento inicial e nutrição do pinhão-manso em função de doses de NPK (p. 80, Dissertação, Mestrado em Ciência Florestal, Universidade Estadual Paulista "Júlio de Mesquita Filho", Botucatu, São Paulo). Retrieved from http://repositorio.unesp.br/bitstream/handle/11449/86484/freiberger_ mb_me_botfca.pdf? sequence $=1$ \&isAllowed $=\mathrm{y}$

Furtini Neto, A. E., Curi, N., \& Guimarães, P. T. C. (2001). Fertilidade do solo (p. 252). Lavras: UFLA/FAEPE.

Giracca, E. M. N., \& Nunes, J. L. S. (2012). Tipos de fertilizantes. Coasul (Cooperativa Agroindustrial). Retrieved from http://www.coasul.com.br/tipos-de-fertilizantes

Gonçalves, N. P., Costa, A. C. F., Saturnino, H. M., Gabriel, D., \& Andrade, L. F. (2009). Artrópodes nocivos aos cultivos de Jatropha curcas L. I Congresso Brasileiro de Pesquisas de Pinhão Manso, Brasília, DF. Anais... Brasília, DF: ABPPM.

Gusmão, C. A. G. (2010). Desempenho do pinhão-manso (Jatropha curcas L.) de segundo ano submetido a diferentes doses e relações NPK (p. 81, Dissertação, Mestrado em Produção Vegetal no Semiárido, Universidade Estadual de Montes Claros-UEMC, Janaúba, Minas Gerais). Retrieved from http://www.producaovegetal.com.br/arquivos_upload/editor/file/dissertacao_carlos_alberto_gusmao.pdf

Heller, J. (1996). Physic nut. Jatropha curcas L.: Promoting the conservation ande use of underutilized and neglected crops (Vol. 1, p. 66). Internacional Plant Genetic Resources Institute, Rome. Retrieved from http://www.bioversityinternational.org/uploads/tx_news/Physic_nut_Jatropha_curcas_L._161.pdf 
Koch, K., \& Menegel, K. (1977). Effect of K on N utilization by spring wheat during grain protein formation. Agronomy Journal, 69, 477-487. https://doi.org/10.2134/agronj1977.00021962006900030036x

Kumar, P., \& Pandey, R. M. (1979). Sampling for mineral content in leaves of guava cultivar 'Lucknow-49'. Scientia Horticulturae, 11, 163-174. https://doi.org/10.1016/0304-4238(79)90041-4

Laviola, B. G. (2009). Nutrição mineral e adubação do pinhão-manso. I Circuito Nacional de Dias de Campo de Pinhão Manso. Anais... Janaúba, MG: ABPPM.

Laviola, B. G., \& Dias, L. A. S. (2008). Teor e acúmulo de nutrientes em folhas e frutos de pinhão-manso. Revista Brasileira de Ciência do Solo, 32, 1969-1975. https://doi.org/10.1590/S0100-06832008000500018

Lima, R. L. S., Severino, L. S., Cazzeta, J. O., Azevedo, C. A. V., Sofiatti, V., \& Arriel, N. H. S. (2011). Redistribuição de nutrientes em folhas de pinhão-manso entre estádios fenológicos. Revista Brasileira de Engenharia Agricola e Ambiental, 15, 1175-1179. https://doi.org/10.1590/S1415-43662011001100010

Lima, R. L. S., Severino, L. S., Ferreira, G. B., Sofiatti, V., Sampaio, L. R., \& Beltrão, N. E. M. (2011). Posição da folha e estádio fenológico do ramo para análise foliar do pinhão-manso. Revista Brasileira de Engenharia Agrícola e Ambiental, Campina Grande, 15, 1068-1072. https://doi.org/10.1590/S1415-43662 011001000011

Lopes, E. P. (2009). Efeito de torta de algodão, mamona, e pinhão-manso na biologia de Fusarium oxysporum $f$. sp. cubense e no desenvolvimento de bananeira "prata-anã” (p. 56, Tese, Mestrado em Produção Vegetal no Semi-árido, Universidade Estadual de Montes Claros, Janaúba). Retrieved from http://www.bivirloc. com/ejournals/PESQUISA\%20AGROPECUARIA\%20BRASILEIRA/2015/pesquisa\%20agropecuaria\%20 Vol\%2050\%20Num\%209\%20Septiembre\%202015.pdf

Maia, J. T. L., Bonfim, F. P. G., Guanbens, R. E. M., Trentin, R., Martinez, H. E. P., Pereira, P. R. G., \& Fontes, P. C. R. (2014). Omissão de nutrientes em plantas do pinhão-manso cultivadas em solução nutritive. Revista Ceres, 61, 723-731. https://doi.org/10.1590/0034-737X201461050016

Malavolta, E. (2006). Manual de nutrição mineral de plantas (p. 638). São Paulo: Agronômica Ceres. https://doi.org/10.1590/S0104-77602011000400003

Malavolta, E. (2008). O futuro da nutrição de plantas tendo em vista aspectos agronômicos, econômicos e ambientais (p. 10). Piracicaba: Internacional Plant Nutrition Institute.

Malavolta, E., \& Moraes, M. F. (2007). Fundamentos do nitrogênio e do enxofre na nutrição mineral das plantas cultivadas. In T. Yamada, S. R. S. Abdalla, \& Vitti, G. C. (Eds.), Nitrogênio e enxofre na agricultura brasileira (p. 722). Piracicaba: Internacional Plant Institute.

Malavolta, E., Vitti, G. C., \& Oliveira, S. A. (1997). Avaliação do estado nutricional das plantas-Princípios e aplicações (2nd ed., p. 309). Piracicaba: POTAFOS.

Marschner, H. (2012). Mineral nutrition of higher plants (p. 889). London: Academic.

McBride, M. (1982). Electron spin resonance investigation of $\mathrm{Mn}^{2+}$ complexation in natural and synthetic organics. Soil Science Society of America Journal, Madison, 46, 1137-1143. https://oi.org/10.2136/ sssaj1982.03615995004600060004x

Mengel, K., \& Braunschweig, L. C. Von. (1972). The effect of soil moisture upon the availability of potassium and its influence on the growth of young maize plants (Zea mays L). Soil Science, 114, $142-872$. https://doi.org/10.1097/00010694-197208000-00010

Morais, D. L. B., Morais, D. L. B., Faria, M. A. V. R., Fernandes, M. B., \& Queiroz, E. S. (2007). Qualidade de sementes de pinhão-manso com base na coloração dos frutos. IV Congresso Brasileiro de Plantas Oleaginosas, Óleos, Gorduras e Biodiesel. Anais... Varginha, MG: CBPOOGB.

Nunes, D. L. B., \& Pasqual, M. (2007). Caracterização de frutos, sementes e plântulas e cultivo de embriões de pinhão-manso (Jathopha curcas L.) (p. 78, Dissertação, Mestrado em Fitotecnia, Universidade Federal de Lavras, Lavras, Minas Gerais).

Oliveira, E. L., Faria, M. A., Evangelista, A. W. P., \& Melo, P. C. (2012). Resposta do pinhão-manso à aplicação de níveis de irrigação e doses de adubação potássica. Revista Brasileira de Engenharia Agrícola e Ambiental, 16, 593-598. https://doi.org/10.1590/S1415-43662012000600001 
Olomu, M. O., Racz, G. J., \& Cho, C. M. (1972). Effect of Flooding on the Eh, pH, and Concentrations of Fe and Mn in Several Manitoba Soils. Soil Science Society of America, 37, 220-224. https://oi.org/10.2136/ sssaj1973.03615995003700020019x

Pathar, R. A., \& Pandey, R. M. (1976). Sampling for mineral content in leaves of mango cultivar 'Dashehari'. Scientia Horticulturae, 5, 255-264. https://doi.org/10.1016/0304-4238(76)90090-X

Ribeiro, M. S. (2009). Caracterização biométrica de sementes de pinhão manso (p. 198). I Congresso Brasileiro de Pesquisas de Pinhão Manso. Anais... Brasília, DF: ABPPM.

Savi Filho, A. M. (1998). Instruções agrícolas para as principais culturas econômicas. In J. I. Fahl, M. B. P. Camargo, M. A. Pizzinatto, J. A. Betti, A. M. T. Melo, I. C. Demaria, \& A. N. C. Furlani (Eds.), Boletim Técnico, 200 (6th ed., p. 396). Campinas: IAC.

Severino, L. S., Ferreira, G. B., Moraes, C. R. A., Gondim, T. M. S., Cardoso, G. D., Viriato, J. R., \& Beltrão, N. E. M. (2011). Produtividade e crescimento da mamoeira em resposta à adubação orgânica e minera. Pesquisa Agropecuária Brasileira, Brasília, 41, 879-882. Retrieved from http://www.scielo.mec.pt/ scielo.php?script $=$ sci_arttext\&pid=S0871-018X2013000300006

Souza, J. L. (1998). Agricultura orgânica-Tecnologias para a produção de alimentos saudáveis (p. 179). Vitoria: INCAPER.

\section{Copyrights}

Copyright for this article is retained by the author(s), with first publication rights granted to the journal.

This is an open-access article distributed under the terms and conditions of the Creative Commons Attribution license (http://creativecommons.org/licenses/by/4.0/). 